JISTEM - Journal of Information Systems and Technology Management

Revista de Gestão da Tecnologia e Sistemas de Informação

Vol. 12, No. 3, Sept/Dec., 2015 pp. 577-594

ISSN online: $1807-1775$

DOI: $10.4301 / \mathrm{S} 1807-17752015000300005$

\title{
THE CONTROVERSIES OF SELF - FROM (INFO) ETHICS TO CYBER TERROR
}

CONTROVÉRSIAS DO EU - DA (INFO)ÉTICA AO TERROR CIBERNÉTICO.

\author{
Jefferson Cabral Azevedo \\ Rosalee Santos Istoe \\ Carlos Henrique Medeiros Souza \\ Bruna Moraes Marques
}

Universidade Estadual Norte Fluminense Darcy Ribeiro, Campos dos Goytacazes, Rio de Janeiro, Brasil

\begin{abstract}
The media relations make possible new structural arrangements regarding the constructions of identities and new paradigms relating to ethical and moral assumptions. Psychic formation processes are influenced by several variables that are interrelated in an open system, converging in anthropological, environmental, genetic, psychological, historical and social factors that determine relational interaction behaviors. However, in virtual cities where flow-image, timelessness and non-place reign, they enable new psychic arrangements and a greater plasticity and speed in processing information and generating knowledge. At this conjectural point, where technology is a key factor that permeates the interactions and offers unknowns in the construction of identities, a new order without standards is established, which rules ethical parameters. The results catalyzed by the speed of exchanges of information characterize deviant and antisocial behaviors that can bring uncountable damage to every human being basic rights.
\end{abstract}

Keyword: Identity formation, psychological structures, social networks, info ethics, Internet crimes legislation.

\section{RESUMO}

Os processos da formação psíquica sofrem influências de diversas variáveis que se interrelacionam num sistema aberto, confluindo sobre fatores antropológicos, ambientais, genéticos, psicológicos e histórico-sociais que determinam os

Manuscript first received/Recebido em: 17/02/2012 Manuscript accepted/Aprovado em: 02/07/2015

Address for correspondence / Endereço para correspondência

Jefferson Cabral Azevedo, Bolsista Faperj e Mestrando pelo programa de Cognição e Linguagem pela Universidade Estadual Norte Fluminense, MBA em Gestão Estratégica de Recursos Humanos pela Faculdade Salesiana Maria Auxiliadora, Psicólogo pela UNESA - Nova Friburgo e Administrador de Empresas pela UCAM.

Carlos Henrique de Souza Medeiros, Doutor em Comunicação pela UFRJ, Professor da Universidade Estadual Darcy Ribeiro - UENF; Coordenador do programa de Mestrado em Cognição e Linguagem.

Rosalee S. C. Istoe, Doutora em Ciências pela Fundação Oswaldo Cruz - IFF/RJ (2007), Mestrado em Psicologia da Saúde pela Universidade Metodista de São Paulo (1999), professora da UENF, Graduada em Teologia - Seminário Teológico Batista do Sul do Brasil (1985) e Graduação em Psicologia pela Universidade Metodista de São Paulo (1991). 
comportamentos nas interações relacionais. Entretanto, nas cidades virtuais onde imperam, a imagem-fluxo, a atemporalidade e o não-lugar permitem novos arranjos psíquicos e uma maior plasticidade e velocidade em processar informações e gerar conhecimentos. Neste ponto conjuntural, onde a tecnologia é um fator primordial que permeia as interações e oferecem incógnitas na construção de identidades, uma nova ordem se estabelece, porém sem um parâmetro ético de normas e regras. Os resultados catalisados pela velocidade das trocas de informação caracterizam comportamentos desviantes e anti-sociais que podem trazer danos incalculáveis aos direitos básicos de todo ser humano.

Palavras-chave: Formação de identidades, estruturas psicológicas, redes sociais e infoética e legislação para crimes na internet.

\section{INTRODUCTION}

In the media society, rapid structural changes occur, endogenous related to identity formation, or exogenous, related to social arrangements. At this historic transition moment between the twentieth and twenty-first century, paradigmatic concepts are rapidly changing, thanks to digital technological advances that have provided a drastic change in communication, economy and behavior processes. The reality hitherto perceived as static, or suffering gradual changes, was completely restructured to relations virtualization, giving place to timelessness and shortening of geographic distances. Consequently, the identities arisen from clashes between these conceptions provide new paradigms concerning behavior flow and psychic structure reference, besides new social and scientific paradigms.

We live in the information age, the rapid changes in social structures and in their relationships. It is not, therefore, a simple matter of point view, it is a role redefinition, not closed and inert anymore, and also a reconstruction of parameters exercised by daily living appropriation. Such coexistence is a distinguished virtualization of digital social network relations and to study them, the current instruments arising from the scientific methodology do not support or give tooling structure in order to comprehend all its idiosyncrasies.

Scientific paradigms are through a model formation comprising a set of theories to explain studied phenomena, thus providing a certain worldview.

It is in this context, investigative processes are complex, because they are related to psychological, sociological, anthropological processes, among others.

It is in this aspect, the processes responsible for human physic formation are characterized as a variables set in an open system that is influenced by environment, genetic heritage and socio historical factors subjectivity.

In this new virtual environment, the current rules regarding regulatory aspects, such as ethics, are liquid and fickle, not offering solid parameters to establish behavior patterns. Therefore, it is necessary to create a new reference that can glimpse the dynamism and plasticity of virtual relationships and that can provide a theoretical and practical instrument in relation to experiences arising from these processes. At this time, info ethics appears as an outline to regulate and dialogue about post modernity social arrangements. 
The definition of identity can be broad due to its various concepts derived from psychology, psychoanalysis, sociology, philosophy, history and social time that a particular culture crosses and their scientific paradigms. And thus, identity is understood as personality, personality trait, identity or even as identification.

For Bauman (2005), to define identity is complex due to its numerous variables. He says that:

In a society that made social, cultural and sexual identities uncertain and transitory, any attempt to 'solidify' what became liquid through identity politics would inevitably lead critical thinking to a dead end. (p.12).

The constructions of identity have suffered enormous technological acceleration influence, disorienting their identification formation processes, primary factor established by Freudian psychoanalysis. The values that once had strong influence, are seen worn by interactivity and fragmentation of secular institutions such as family and religion. According to Caar (2011), we are in a sphere based on relations' superficiality and they are permeated by artificiality, making psychic formation process a tangle of possibilities, generating diverse alternatives and possibilities to create new identities.

Bauman (2005), to define these opportunities of multiple identities formation, establishes the crisis sense created by postmodernity, using the Liquid Identity concept, a term used to characterize the liquid flow. Liquid life mentioned by Bauman (2005) reflects the uncertainty. The author considers that "(...) the liquid life is a precarious life, lived in constant uncertainty conditions ." (p 08).

The identity issue is also linked to the Social Welfare State collapse and the further insecurity sense growth, with "character corrosion of " that insecurity and flexibility in workplace has caused in society. (BAUMAN, p.11)

Bauman (2005) also refers to the ideological processes that enabled the security feeling and social reference, but ideologies have become liquid and, with globalization, the cultural aspects fragmented.

In our liquid-modern era, the world around us is divided into illcoordinated fragments, while our individual existences are sliced in a succession of loosely connected episodes. Few of us, if anyone, are capable of preventing the passage by more than an "ideas and principles community," being it genuine or supposed, well-integrated or ephemeral, so most have problems to solve (...) the issue of la mêmete (the consistency of what distinguishes us as people, whatever). (p.19)

Globalization, combined with Internet use, deterritorializes cultural conceptions and directly and indirectly influences identity formations and establishes a universal belonging sense, besides:

(...) We can safely say that globalization, or better, the "liquid modernity" is not a puzzle that can be solved based on a preestablished model. Rather, it should be seen as a process, as its comprehension and analysis - just as the identity said on the multiculturalism crisis, or in Islamic fundamentalism, or when 
the internet facilitates the ready to use identities expression. (...) Identity politics thus, speaks the language of those who were marginalized by globalization. But many of those involved in postcolonial studies emphasize that the use of identity should be considered a continuous process of redefining oneself and to invent and reinvent his/her own history. That's when we discovered the identity ambivalence: the past nostalgia coupled to full compliance with the "liquid modernity". (...) Whatever the research field on which one can test identity ambivalence, it is always essential to distinguish the twin poles it imposes to social life: oppression and liberation." (BAUMAN, 2005 p.1013).

The post modernity effects on identity formation are well described by Stuart Hall (2005) in his book "The Cultural Identity in Post-Modernity," besides highlighting the individual change process in the late twentieth century, which affects the individual identity formation processes. Hall emphasizes that:

(...) Sometimes, as our postmodern world, we are also "post" regarding to any fixed or essentialist identity conception something that, since the Enlightenment, is supposed to define our being, own core or essence, and conveying our existence as human subjects. (P.10).

The dynamic factors exposed by Hall (2005) bring essential features to the relationship between the various existing connections in post modernity and their bends to identity formation. He says:

(...) We internalize their meanings and values, making them "part of us", to align our subjective feelings with objective places that we occupy in the social and cultural world. The identity then sews (or, to use a medical metaphor, "sutures") subject to structure (...) It is argued, however, that these are things which now are "changing". The subject, previously lived as having a unified and stable identity, is becoming fragmented; made of not a single but several identities. (p 12).

In this tangle of possibilities, the subject can take contradictory identities, depending on the moment and situation. Hall (2005) states that there is a slip on identity concept, and the subject presents a diversity of identities, however fragmentary and inconsistent. In this sense, Hall (2005) proposes to speak of identification and not identity, because the fragmented subject ceases to be cohesive, has a multiplicity of "Selves" and, through the linguistic process, it attempts to close a plot on these various subjects.

Lévy (2000) tells us that the psychic formation processes are structured in a space able to establish meanings, providing the construction of identity, identification, attributes. Lévy (2000) reports that people do not relate only in a physical space, but also in spaces that have a meaning.

Within this context, it is important to highlight certain aspects, such as set of cultural attributes and their inter-relationships and, above all, the symbolic construction.

According to Freud (1969), in Totem and Taboo, the identity is established at our psychic apparatus (that we were born with) intersection and external reality. What 
exists outside us is called human society, with its institutions and norms. This identity sense allows us to have a sense of continuity, whic we are always the same regardless the time we are living in, whether in past or present.

It is in this perspective that we can analyze the subject constitution by culture, whether psychological or materialistic. Freud (1969), in Totem and Taboo, refers to human institutions as a thinking way product, both marriage institutions as group marriage, both institutions with religious characteristics as Totemism, or even the economy that goes through all other institutions.

To Maia (2007)

The postmodern subject identity is no longer taxed as fixed or permanent, as happened in the Enlightenment. It comes to understand that the individual can take different positions, according to the role represented, generating an identification process that is not automatic, but that can be won or lost over the course of their trajectory. Everyday life complexity, crossed by globalization, which shortens distances and connects communities in new space-time structures, requires that we assume different identities that may conflict with each other. We position ourselves facing each other in accordance with the expectations laid upon us. (p. 04)

Maia (2007), citing Hall (1999), emphasizes on identity crisis aspect in postmodern society and argues that:

The fragmented subject is characterized by having multiple cultural identities - that can be contradictory or not - temporary, variable and often problematic. The postmodern individual takes a "moving" and "temporary" identity - a possibility among many possible - according to time and place. This is because the construction of identity takes place in interaction with others and "by the ways in which we imagine to be seen by others" (HALL, 1999) - lifelong, making a constant change and formation process. (p. 06)

According to Souza (2006), these established values are given through the "cultural industry that massifies and alienates, standardizing identities and excluding any individual possibility of constructions of identity."

This cultural industry is strengthened today by the Social Networks and Internet cult that has surpassed television as a major means of entertainment. Social Networks had rapid social acceptance, directly and indirectly influencing the customs and habits of the most diverse populations and social classes.

Within this dialogical process between psyche and social is that, at present, social networks allow a significant range, which can offer a greater symbolic field to influence identity formation.

According to Castells`(2002) prospect,

(...) Networks are open structures able to limitless expantion, integrating new knots since they can communicate within the network, that is, since they share the same communication codes (for example, values or performance objectives). A social 
structure based on networks is a highly dynamic open system, capable of innovation without threats to its equilibrium. (p. 499)

This process dynamics offers a huge change from the earlier cases due to its speed, information quantity and accessibility, besides, of course, interactivity. The subject is not a mere viewer, listener or reader; s/he comes out of a passive receiver figure and becomes transceiver.

In this interactive process, it should be noted that technological development experienced in recent years, especially in the late twentieth century, with Globalization as catalyst, has enabled the enormous changes in the communication concepts and subjectivity formation. However, these subjectivity changes, either as a cause or consequence, modifies and transforms the social structure and its power relations, besides allowing a new culture based on information appearance.

Castells (2002), in "The identity power" reports that many of the social changes experienced in the last years of the twentieth century were capitalism restructuring consequences, when knowledge and information acquired a crucial role in the production processes and social transformations essentially changed labor relations.

These power relations, according to Foucault (2001), relapse in body control, marking spaces and defining potential conduits for each gender. The controls have idiosyncrasies in their macrostructure regarding to the social system, but finds a fertile propagation field when crystallizes or becomes natural in the microstructure field, mainly in the speech use as ideological spreader, and thus, persuasion instrument among pairs.

These relations are marked by power, emphasized by Foucault (2001), in Microphysics Power, in its imperative aspect in, physical or imaginary, bodies, under discipline tutelage.

But finally, what is the difference and the relationship between information and knowledge? To enter this relationship, one should keep in mind some important aspects to support a methodological process. Information, according Setzer (2004), from USP Computer Science Department, is formed from data that are codes that constitute the information essence, that is, a group of symbols. Data alone cannot convey a message or can transmit several messages because, according to linguistics, they represent more than one meaning.

For Hall (1999), the subject is not a passive element in a communication process it is active and performs a negotiation around the meaning, depending on variables such as cultural, social, economic context and other determining factors for rejection or acceptance of the reading performed by the individual. The author also argues in his media discourse studies, the code mode against the decode model, that is, the text meaning lies somewhere between the producer and the reader. The producer presents his/her coding claims, while the reader will decode them differently from who produced them, what s/he calls the "understanding margin."

According to Setzer (2004), information is processed data and processing results. Information has meaning; decisions can be taken or statements made based on information. For the author, "a message becomes information if its receiver can understand its content; that is, he/she mentally assigns a meaning to it." Knowledge however transcends the informational factor because it must have an application, not the conception`s pragmatic act, but abstraction and ideas production, providing knowledge, that is, worked information. 
If the invention of printing, provided by Gutenberg, made access to information possible and perhaps, to knowledge, taking the man from Middle Age, the computer development and later the internet, to technological advances arising after the Second World War, providing a mass communication catalyst, that is, information acceleration,according to Souza (2009), "Technologies and new communication modes: Knowledge (Re)Invention", a new paradigm, which:

(...) Requires, therefore, a new way to build knowledge, which should be preferentially oriented to what happens in today`s world, and this cyberspace of possibilities can provide great propriety, as it offers a data range that can be independently accessed in electronics devices at home, work, school, church, and leisure places, whose main characteristics are changing and multiplying. A non-place, so called by many a new expression way where we can form, invent and fabricate concepts. (p.17).

The computer invention removed the man from the place he was, from space itself, and put him in the non-place. In this context, the school and the family are not the only reference for identity formation and psychic structure, the non-place provided by new technologies entered such restricted environments and contributes to establish new values and interaction parameters, of relationships and power propagation, besides identity formation, whether pathological or not.

Souza points out in "Communication, Language and Identity" (2006), the concept developed by Turkle (1997):

In identity construction history in the simulation culture, experiments on the Internet occupy a prominent place, but these experiences can only be understood as part of a wider cultural context. This context is the history of the erosion of boundaries, between real and virtual, animated and inanimate, unitary self and multiple self, taking place both in the cutting-edge scientific research fields and in everyday life pattern. (p. 12).

\section{THE SELF CONTROVERSIES}

It is important to try to understand that the subject structuring aspects are not necessarily relative and solely directed to intrapsychic processes; they are multi-causal aspects that encompass the necessary biological structures so that the psychic apparatus is established and developed, including social, cultural and gender processes.

Within the psychoanalytic perspective, the subject development is similar and correlative to the civilization development, that is, if an individual psychic structure is similar and correlative to a civilization structure, we have, in this sense, a psychic constitution prospect extension, leaving its hermetically closed character in pure subjectivism, to a character in which man comes to be defined as relations from the result of the systems that integrate relations.

Every civilization needs the development of a particular culture that requires specific rules and regulations in order to live collectively, besides ensuring success for knowledge acquiring and thus being able to control natures's natural forces and achieve human needs satisfaction. 
Freud (1969), in An Illusion Future, states that:

The instinctual wishes that were under them are born again with each child. There is a people class, the neurotics, who react to these frustrations through an asocial behavior. Among these instinctual wishes we can say the cannibalism, incest and lust for killing. It sounds strange to place side by side desires that have such a vivid dispute in our civilization as permission or frustration; psychologically, however, it is justified to act so. Nor, anyway it is uniformly the civilization attitude toward these old instinctual desires. (p. 56)

It is through this internalization of the Other and conduct standards, that we shrink back our instinctual instinct, based on pleasure principle, and coercively accept the norms and rules imposed by current society, determining human behavior based on reality principle, as well as construction, Superego structuring. In this context, Freud (1969) states that:

(...) Every civilization has to be built on coercion and instinct renunciation; it does not even look right if, it happened to cease coercion, most people would be prepared to undertake the necessary work to acquire new wealth. I think one has to consider the fact that they are present in all men destructive tendencies and therefore anti-social and anti-cultural, and that in a large number of people, these trends are strong enough to determine their behavior in society human. (p. 23)

The identity formation process in the network runs through several interesting aspects and tragic at the same time, because according to Freud (1969), personality formation happens through and by the Other. However, who is this other within a technologically virtual world where relationships are ephemeral and transitory? Sometimes the Social Networks act as a large group that influences the components behavior and subdues the individual identity. For Le Bon (1969), "the individuals particular skills erase in a group and, thus, her/his distinctiveness fades." According to Freud (1969) in "Mass Psychology and ego analysis", there are two important factors:

The first is that the individual who makes part of a group acquires only by numerical considerations, an invincible power feeling that allows him/her to yield to instincts that if s/he were alone, s/he would compulsorily kept under coercion. S/he will be even less willing to be controlled by the consideration that, being an anonymous group and, therefore, irresponsible, the responsibility sense which always controls individuals disappears entirely. (p. 42)

Another important factor is the infection relation by which individual behavior is directly influenced as the "herd effect": the insight and self-will disappear altogether passing thus to assume a group identity.

In this object relationship that could be understood as the subject relationship with his/her world, we have some important aspects related to this panorama, as an ego ideal imposed from the outside and the conditions it imposes to libido satisfaction. 
When Hall (1999) mentions family and religious institutions, state and school, failure, as the only influences purveyors, rules and standards, he sets new parameters for the subject structure.

In this world that permeates the real $\mathrm{x}$ virtual, imaginary and the symbolic change, important issues concerning the psychic process structuring are highlighted. In this context, there are important issues relating to superego structuring, because parental and social demands expressed are distinct and different from virtual requirements and therefore more flexible and dynamic and less repressive, inflicting this context a lower valence to print censorship and internalize limits, enabling greater ID performance and therefore the pleasure principle on behavior, providing greater instinctual drives satisfaction. The virtualization of society relations on digital networks offers a huge significant range for the subject to satisfy his/her instincts, circumstantially decreasing desire sublimation.

This context allows a greater permeability so that the subject transits without embarrassment by virtual cities and establishes new significance for the Self Ideal formation. There is in this process a libido reinvestment in the own self (narcissistic) what the subject looks for is to be desired, s/he aims at the other's desire and thus to berecognized in the digital social network to satisfy she/her narcissistic needs.

For Freud, the censor rejects these conditions. This censor is quoted as different from censorship, that is, an external mechanism that promotes a libidinal flow compatible with its requirements, bringing satisfaction.

This external mechanism that imposes conditions for satisfaction realization we can call the Other, because it is the one that provides possible mechanisms, which regulates, that determines, as stated earlier.

Thus, in dialogical relations between authors such as Sigmund Freud and Donald Winnicott, the writers do see that the truth notion is socially constructed, but the superego strength weakening in cyberspace environments generates an id power increase, so that the subject exposed to these Internet practices just assume there, a different subjective disposition from the one that has out of virtual reality. In this sense, there is a difficulty to homogenize his/her identity.

Freud (1969) points out that the truths building process is dynamic and has a huge psychological variables range influenced by cognitive aspects, perceptions, settlements, etc. This processes tangle is what enables each individual create her/his own truth. And in some cases his/her own roles or identities, or better, his/her identification. These variables cross the

(...) Cultural requirements already mentioned, the internalization seems to have been largely achieved, if we do not consider the unpleasant neurotics exception. However, the case is altered when we turn to other instinctual demands. Here we note with surprise and concern that most people obey cultural prohibitions on these points only under external coercion pressure, that is, only where such coercion can be effective and while it should be feared. This is also true as to what is known as civilization moral demands, which, likewise, apply to all. Most of experiences of man's moral unreliability occur in this category. There are countless civilized people who refuse to commit murder or to practice incest, but not refuse to satisfy their greed, their 
aggressive impulses or their sexual desires, and do not hesitate to harm others through lies, fraud and slander, since they can go unpunished; it undoubtedly was always this way through many civilization ages. (p. 43)

Social networks produce fascination and enchantment, providing relationships timelessness. For Souza (2005), this world includes and permeates many changes in modern society, brought by Cyberculture. We infer that we are facing a new space social production form, in which the instantaneous real-time is a time out of time and the new day-to-day is devoid of space and matter. The flow-image, presentification, virtual reality and the various communication possibilities in cyberspace suggest a new environment: the digital cities. Virtual reality that presents itself in cyberspace is not only sensory contemplation fruit of images and information exchange, but an objective way of the new social arrangement materiality in communication networks and, it can be said as, a new psychic structuring variable.

Winnicott (1990), in his psychoanalytic theories, developed the false self concept to represent an identity that will be accepted for the own subject and for Others, mediated by the culture that surrounds it. This false identity or personality conceals the real, permeating thus a conduct based only on the facts appearance.

Winnicott (1990) quotes a false self organization classification at different levels, from pathology to normal, such as:

- the false self used and treated as real, hiding the true self;

- the false self that defends and protects, but that feels the true self as a potential and preserves it in a secret life;

- the false self which deals in finding environmental conditions that allow the true self begin to exist,

- the false self made on introjected identification throughout life, and, in normality,

- the false self as appropriate social attitude, protecting a true self that is alive. (p. 46)

This conception also approaches the idea of "Persona", Archetype, developed by Jung, which states that we all create roles and act as circumstances require from us. We use several Personas throughout our lives according to the environment in which we live. However, with flexibility and dynamism present in social networks, mediated by technology, it is allowed that these roles, that is, the Persona, come alive in this "nonplace", allowing the subject to be anything but themselves. This "self" objectification and "THING embodiment forced by the Personas maintenance in Networks produce an immense emotional gratification and at the same time, a huge insecurity feeling, besides a giant psychic energy expenditure to keep up these roles appearances.

Hall (2005) emphasizes that, in postmodernity, identity becomes a

(...) mobile celebration, since the subject assumes different identities, and these vary according to the time, so we can suggest that the subject identity becomes a "Self extension, through the relationship with its avatar immersed in cyberspace. The old identities are declining, giving rise to new identities and causing the modern individual fragmentation: "(...) this loss of a 
stable 'self sense' is sometimes called subject shift or decentralization" (pp.7 -9).

To Reule (2007), the identities experienced in cyberspace are masks that can be exchanged at any time. He states that the relationship spaces protect the individual's identity and shamelessly allow exposing the ideas and desires that the subject in the real world could not expose, because in the virtual world the censorship power is smaller. This brings numerous opportunities to adopt different identities.

There is an "Own Self" reformulation by users of digital networks, constantly changing their identity or attributes, whether in substantive aspect (name) or adjective aspect (qualities), thus making a subject fragmented between what $\mathrm{s} / \mathrm{he}$ is and what $\mathrm{s} / \mathrm{he}$ would like to be. This dichotomy between the Self and what it would like to be, makes Fake existence possible - false descriptions.

Mocellim (2007) made reference to the Fake topic as a name used by the subjects who are interrelated in digital social networks and use profiles with false information:

Someone cannot be considered a fake of him/herself; in cases that people expose facts or characteristics that do not correspond with him/her in fact, users often say that the person is creating another identity, creating a character, being false, exaggerated. But fake serves for cases that one actually seeks to be someone else, declaring to be another, and not being the same, only describing or acting in a different way than expected by people who know him/her personally. (p.10).

The fakes can be understood as identity fragmentation aspects and as the masks (personas) that subjects use in virtual relationships.

In the writings developed by Jung (1961), Persona can be understood as the mask with which we present ourselves to the world. It is like a complex personality by which we interact with the environment. The Persona includes social roles, expression and communication types. It presents positive and negative characteristics that protect us from forces that invade us. Therefore, the subject can consciously or unconsciously adopt an artificial or masked personality reverse from his/her character traits. We assume different Personas depending on the environment in which we find ourselves.

Such uncertainty provides an often-compulsive behavior so that the true "Self" does not come to surface. This false appreciation instead of the own "Self" produces deviant and even pathological personalities in the "FAKE" is part of a subjected, or even disguised "FACE" because to demonstrate the true Self could bring the inexorable and imponderable, as socially unacceptable behavior, such as paraphilia-related disorders like pedophilia, necrophilia, voyeurism, fetishism, sadism, masochism, among others, besides those related to psychopathy or simply bring to social recognition an image produced to get visibility, or acceptance, through it.

In relations' virtualization, implicitly, we can see the Visibility Power. The search for visibility within the network can bring behaviors that are not allowed in "Real" world, where relationships are marked by norms and rules. Such rules and regulations are not established in networks and are thus subjective, with little capacity or strength to generate critical sense. In this context, we witness the artifices use to achieve visibility going over Ethics and Morality. 


\section{FROM CYBER TERROR TO (INFO) ETHICS}

Some aspects are important to be highlighted in these virtual relationships. Why is certain information propagated and permeated by technology?

Before infer about this aspect, it is necessary to understand the historical processes that influence psyche and directly society cognitive and linguistic processes.

For Castells (2005)

(...) Without doubt the ability or inability of societies to master technology, and especially those technologies that are strategically decisive in each historical period, traces their destination so that we can say that while it does not determine the historical evolution and social transformation, technology (or its lack) incorporates societies transformation ability as well as the uses societies, always in a conflictive process, decide to give to their potential. (p. 04)

The oral language invention and subsequently written language allowed an undeniable technological advance and social groups life way, providing structural changes in relation to information dissemination and its impact on new paradigms restructuring by changing the Power relations and generating constructs that break space, place or territory and time, allowing fluidity and dynamism.

According to Maximiano (2000) and Drucker (2001), the profound changes in labor relations and the introduction of new technology in production and management area required and require a circumstantial change in old Taylor-Ford paradigm, in which education requirements were lower, because work did not need great knowledge. Today, the market demands a subject able to adapt to technological realities, the constant changes and who presents ability to interact with the most diverse environments, whether cultural, social or scientific, needing therefore a more enhanced education level.

The term network society refers to a structured social composition in virtual environment or cyberspace symbolic space, from information circuits derived from microelectronics-based technologies advancement that gave rise to the Internet, the computer-mediated global communication backbone in the early 90. The Internet is more than just technology; it is the means of communication that makes the current societies organizational infrastructure. The Internet is a new socio-technical paradigm heart that is, in fact, the material basis of our lives and our relating, working and communication ways. What Internet does is to process the virtuality and turn it into our reality, making the network society, which is the society we live in.

According to Souza (2005), we are facing several changes in modern society, brought about by Cyberculture. We infer that we are facing a new space social production way, in which the instantaneous real-time is a time out of time and the new day-to-day is devoid of space and matter.

In this reflection we can see that this dynamism of all that is contained in cyberspace creates new ambiences, habits and behaviors - there is no way to ignore or simply avoid these facts. Souza (2003) also warns that technologies succeed each other 
one by one and today's new is a maturing result of an evolution that progressively develops, that is, today's new is the advanced yesterday and exceeded tomorrow.

The flow-image, presentification, virtual reality and the various communication possibilities in cyberspace suggest a new environment: the digital cities. Virtual reality that presents itself in cyberspace is not only image sensory contemplation fruit and information exchange, but also an objective way to be the social arrangement new materiality in communication networks.

\section{METHODOLOGY AND RESULTS ANALYSIS}

In scientific investigation purpose to this research, qualitative and quantitative approaches were used. According to Souza, Manhães and Kauark (2010 p. 26), qualitative emphasizes the phenomenological field, "(...) this is an inseparable link between the objective world and the subject subjectivity that cannot be translated into numbers", while the quantitative defines what is measurable, "(...) which means translate into numbers opinions and information to classify and analyze them."

The process used to obtain data was to extract information concerning sites number on Google and views number on YouTube. The themes choice was made through an analysis related to matters that infringe civil and criminal law, such as racism, racial segregation, homophobia, break-ins, bombing buildings and killing people. The modus operandi for achieving the benchmarks occurred randomly for each discussed topic, with a 10\% visitation of sites found in Google's and YouTube records.

The survey was conducted during the years 2014 and 2105, in Google and YouTube, intercalated, from December to March, to be able to establish a more consistent methodological parameter and not a time frame. From the collected values, we obtained two references that were added and the average established. After collecting the data themes, they passed by a tab process to quantify the found records number. The data are shown in the following graphs and tables: 


\section{Google - Graph - Sites Quantity}

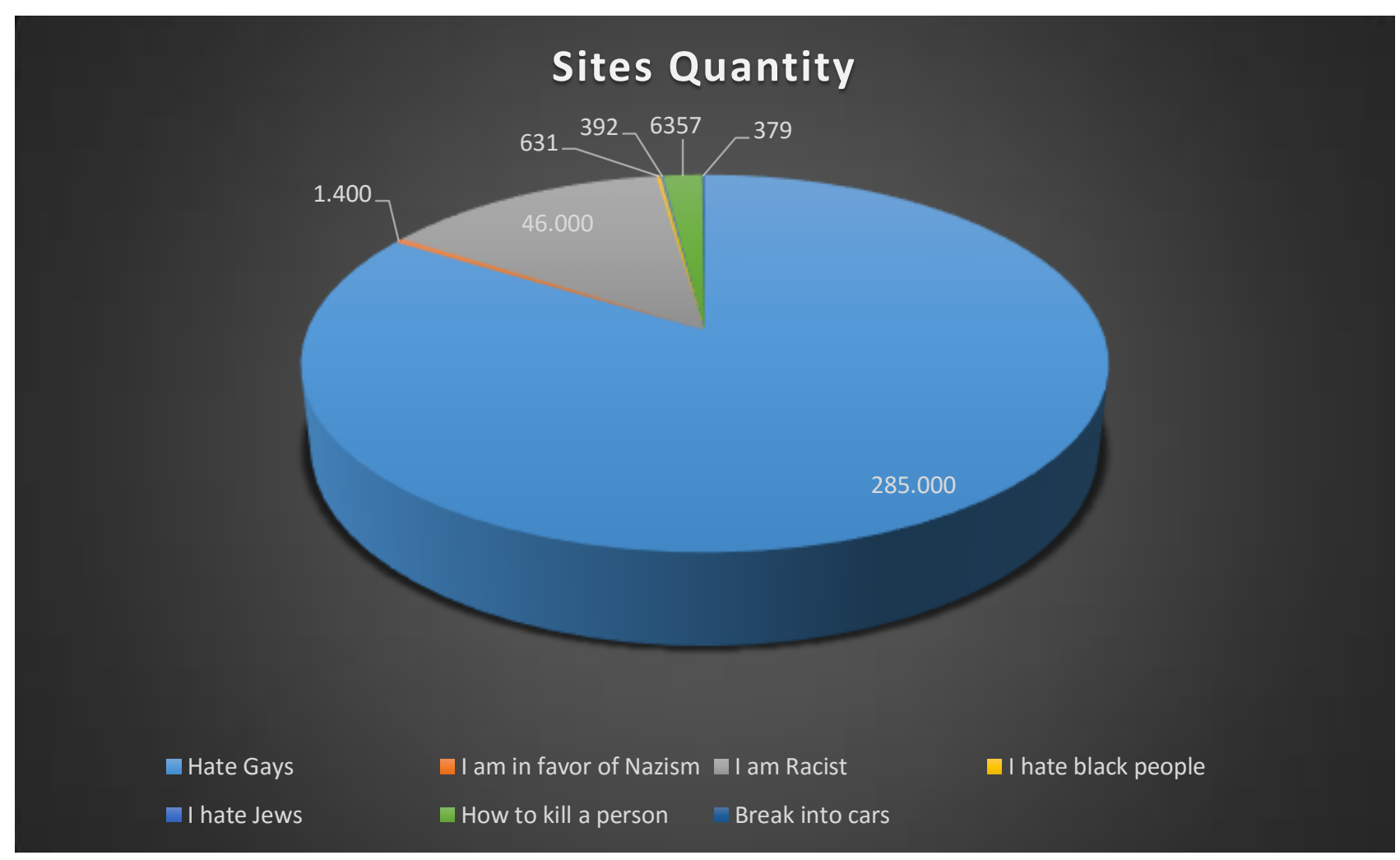

Graph 01: Sites quantity. Search Source.

\section{Google - Table - Sites Quantity}

\begin{tabular}{|c|c|c|}
\hline Items & Themes & Sites Quantity \\
\hline A & Hate Gays & 285.000 \\
\hline B & I am in favor of Nazism & 4.400 \\
\hline C & I am Racist & 631 \\
\hline D & I hate black people & 392 \\
\hline E & I hate Jews & 6357 \\
\hline F & How to kill a person & 379 \\
\hline G & Break into cars & \\
\hline
\end{tabular}

Table 01: Google - Themes and sites quantities. Search source. 


\section{YouTube - Graph - Views Quantity}

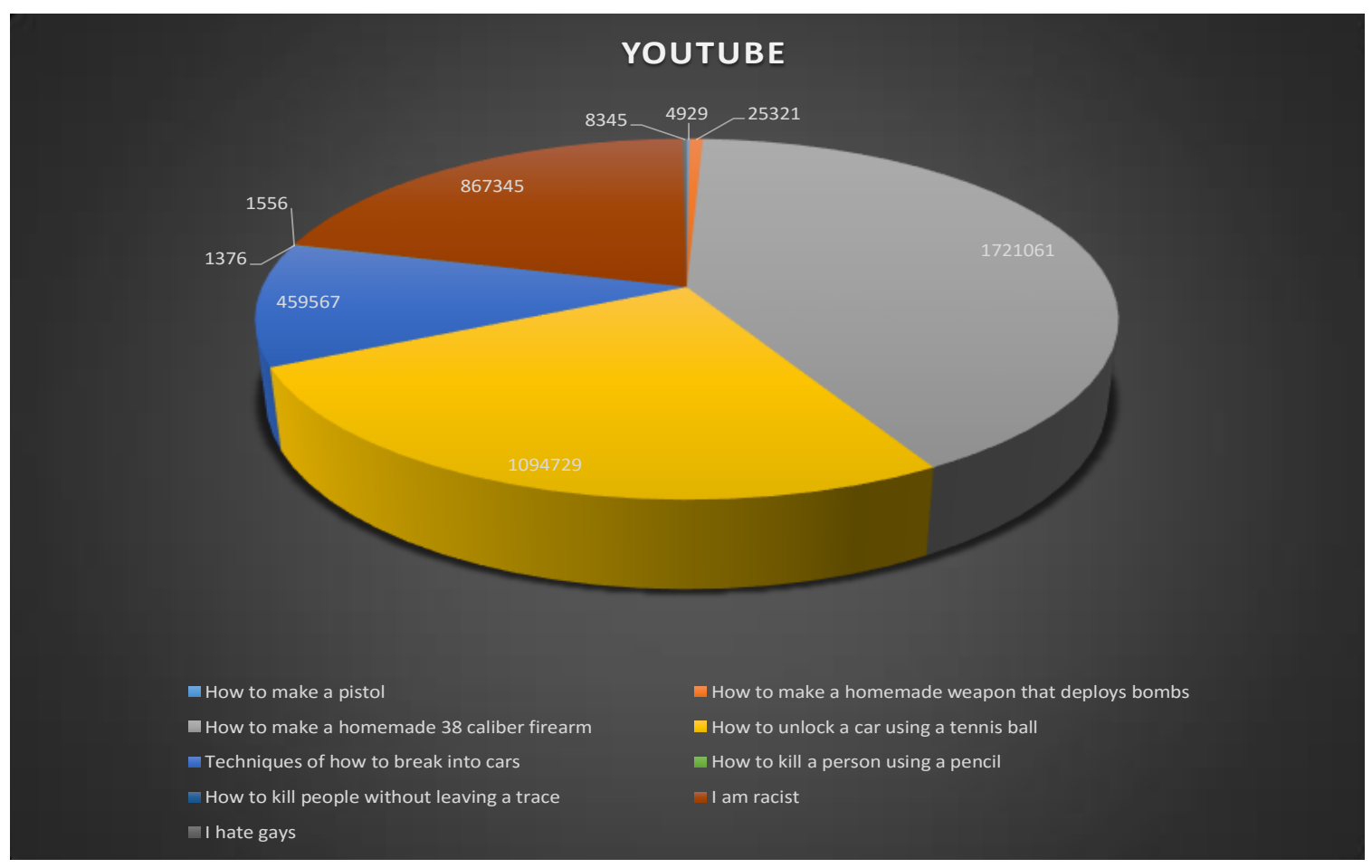

Graph 02: Views Quantity. Search source

\section{YouTube - Table - Views Quantity}

\begin{tabular}{|l|l|r|}
\hline A & How to make a pistol & 4929 \\
\hline B & How to make a homemade weapon that deploys bombs & 25321 \\
\hline C & How to make a homemade 38 caliber firearm & 1721061 \\
\hline D & How to unlock a car using a tennis ball & 1094729 \\
\hline E & Techniques of how to break into cars & 459567 \\
\hline F & How to kill a person using a pencil & 1376 \\
\hline G & How to kill people without leaving a trace & 1556 \\
\hline H & I am racist & 867345 \\
\hline I & I hate gays & 8345 \\
\hline
\end{tabular}

Table 02: Themes e views quantity. Search Source.

There is a great need to reflect the information impact on the digital society and its direct and indirect implications in setting new morality and ethics standards.

With Internet Civil Mark regulations, Law No. 12,965, sanctioned by president Dilma Rousseff on April 23, 2014, the providers are exempt from liability to other postings. As there were no specific rules, some judges used the prerogative that sites 
and providers were co-responsible for offensive pages display. Now, however, they will only be penalized if they fail to accept the court orders to withdrawal publications and offensive material as described in Article 10 and 14. Accordingly, only the Internet users who make offensive posts will be penalized.

The Internet and social networks are not free from historical and social influences. The dynamism and timelessness provide that certain manifestations are catalyzed, amplifying its results. To say that Internet was a milestone for information spread and knowledge production is an irrevocable fact; however, it should also be said that there is not a conduct Ethics conception within this new reality yet. The info Ethics is still embryonic.

In the last months, the so-called Islamic State extremists have been using social networks to demonstrate their power and spread terror to international community, showing beheadings and burning prisoners who are not their religion followers, as well as attracting new members with an offensive marketing over the world. This raises the ethical question.

The fact that the Islamic state uses the digital network to spread terror is not new on Internet. In 2007, Cho Seung-hui, 23 years old, was responsible for the largest massacre recorded in an American university: there were 32 dead and 21 injured videos posted on Internet were his attempt foreshadowing.

In Brazil, "Realengo massacre" happened on April 7, 2011, caused by Wellington Menezes, who killed 12 students. The killer used 38 and 32 caliber guns, besides speedloaders that, according to the police, did not need training. After investigations, it was found that the knowledge for the speedloaders use was from the Internet. Many speculations were made in the media regarding this attack, like several others, talking about psychopathy, hallucinations and delusions, which are common in schizophrenia, bullying, and religious fanaticism, among others. But what drew the most attention was the killer's sister's testimony who said that he "lived on the internet". Even his suicide note was posted on his personal Orkut page.

Of course the Internet is an environment conducive to information spreading and its use is not limited to individuals considered normal within the current scientific paradigm. Those with mental disorders or psychotic spectrum are also virtual world users.

Also in 2008, the Vatican published a manifesto supporting a greater discussion about the Info Ethics development. Benedict XVI (2008) pointed out that it is "essential that social communications carefully defend the person and fully respect human dignity."

\section{FINAL CONSIDERATION}

The information age apogee brings new challenges related to ethical and moral parameters development, because previous standards do not provide agility and the needed mechanisms for setting behavior standards that meet civil society needs. The relations plasticity and liquidity spread up to the identity structuring, which produces instability of the institutional frameworks as State, Family and Religion and enables an exogenous and endogenous mutability for the new mental processes and social arrangements. 
Within the information economy, the domain on the Internet becomes power factor and establishes new social, cultural, anthropological and psychological relations, changing the historical and social processes dynamism and the speed, causing standards and current rules transformation.

Featuring an Info Ethics that will regulate and regularize such virtual environments is of utmost importance for society in general, providing a safer environment and less inclined to crimes and apologies that hurt the citizens' rights.

However, we should conduct a great analysis so that the Internet does not get plastered, making it impossible for information and knowledge to propagate freely, besides being a complaints and protests environment. But freedom is not synonymous with irresponsibility, or even humanity rights transgression.

\section{REFERENCES}

BAUMAN, Zygmunt. Identity: Interview with Benedetto Vecchi. Rio de Janeiro: Jorge Zahar Editor, 2005.

BAUMAN, Zygmunt. Liquid modernity. Rio de Janeiro: Jorge Zahar Editor, 2000.

CARR, Nicholas. What is Internet doing to ours brains: The superficial generation.

Rio de Janeiro. Agir 2011

CASTELLS, Manuel. The network society - the Information Age: economy, society and culture; v. 1. 6. ed. São Paulo: Paz e Terra, 2005.

. The Identity Power. v.2. $5^{\text {th }}$ ed. São Paulo: Paz e Terra, 2001. in The information Age: economy, society and culture.

ICD-10: Mental Disorders and Behavior Classification. Porto Alegre Editora Artmed, 2009.

DE SÁ PINTO TOMÁS, Júlia Catarina. A social invisibility, a phenomenological perspective. Lisboa New University. June 25 2006. Available at http://www.aps.pt/vicongresso/pdfs/285.pdf. Acessed on May 15, 2010 at 16:31.

DRUCKER, Peter Ferdinand. The best of Peter Drucker: management. São Paulo:Nobel, 2001.

FOUCAULT, Michel. Power Microphysics. Rio de Janeiro: Graal Editions, 2007, 23th Edition.

FOUCAUlT, Michel. Discipline and Punish: The Prison Birth. Vozes, 12th Ed - RJ $-2001$

FOUCAULT, Michel. Sexuality History. 16th Ed Rio de Janeiro: Grall, 1998

FREUD, Sigmund. (1912) Totem and Taboo and other works. In: E.S.B., vol. XII. Rio de Janeiro: Imago, 1969.

(1914) Psychoanalytic movement history. In: E.S.B., vol. XXI. Rio de Janeiro: Imago, 1996.

(1921) Mass Psychology and the analysis of the ego In: E.S.B., vol. XXI. Rio de Janeiro: Imago, 1996.

(1917 [1915]) Mouring and Melancholia. In: E.S.B., vol. XXI. Rio de Janeiro: Imago, 1996.

(1927) An Ilusion Future. In: E.S.B., vol. XXI. Rio de Janeiro: Imago, 1996.

(1930 [1929]) The civilization and its discontents. In: E.S.B., vol. XXI. Rio de Janeiro: Imago, 1996.

(1921) Group Psychology and the analysis of the Ego. In: E.S.B., vol. XXI. Rio de Janeiro: Imago, 1996. 
HALL, Stuart. The Cultural Identity in Post-modernity. 10th ed. Rio de Janeiro: DP\&A Editora, 2005.

JUNG, Carl Gustav. The Archetypes and the Collective Unconscious - Complete Work. Petrópolis- 7th Ed. - 2011 VOZES

JUNG, Carl Gustav,. Analytical Psychology - Complete Work. Petrópolis- 7th Ed. 2011 VOZES

MAXIMIANO, Antonio César. Administration General Theory: from scientific school to globalized economy competitiveness. 2.ed. São Paulo: Atlas, 2000 MAIA, Aline Silva Correa. Soap opera projection, identity and identification in liquid modernity. Juiz de Fora Federal University. Minas Gerais, August, 2007.

Available in http://www.compos.org.br/files/24ecompos09_AlineMaia.pdf. Accessed on May 15, 2010 at 15:30.

MENTAL DISORDES DIAGNOSIS AND STATISTICAL MANUAL V. Porto Alegre Editora Artmed, 2014

MOCELLIM, Alan. Internet e Identity: the Orkut website stud. Electronic Journal of Policy Sociology Post-Graduates at UFSC Vol. 3 n. 2, 2007, p.100-112. Available at: <http://www.bocc.ubi.pt/pag/mocellim-allan-internet-e-identidade.pdf $>$. Accessed: October 25, 2010.

LAW PROJECT N. 12,965, APRIL 23, 201: Internet Civil Mark. Available in http://www.camara.gov.br/sileg/integras/912989.pdf Accessed on January 25, 2015.

REULE, Danielle Sandri. Masks and show: postmodern subject building ways. Intercom - Communication Interdisciplinary Studies Brazilian Society. XXX Communication Sciences Brazilian Congress. 2007. Available at: http://www.almanaquedacomunicacao.com.br/files/others/intercomdemascaraseespetac ulo.pdf. Accessed on May 18, 2011

SETZE. Valdemar W. São Paulo University(USP), October 2004. Available in http://www.ime.usp.br/ vwsetzer/dado-info-Folha.html. Accessed on June 12, 2011. SOUZA, C. H. M. Communication, Education and New Technologies. Campos dos Goytacazes, ed. FAFIC/Grafimax, 2003.

SOUZA, C.H.M. e COSTA, M.A.B. Cyberspace and Cyberculture anthropological approaches. In: TB Magazine, Rio de Janeiro, 163: 85/94, oct-dec, 2005.

SOUZA, Carlos H.M. Communication, Language and Identity. North Fluminense State University - UENF, September 2006. Available at: http://www.intercom.org.br/papers/nacionais/2006/resumos/R0240-2.pdf. Accessed on May 25, 2010 at 19:30.

SOUZA, Carlos Henrique Medeiros de, MANHÃES, Fernanda Castro e KAUARK, Fabiana. Research Methodology: A Practical Guide 2010.

SOUZA, Jessé (Org). Brazilian inequality invisibility. Belo Horizonte: UFMG, 2006. TURKLE, Sherry. Life on the screen. The identity in the Internet Age. Lisboa, Relógio D'água, 1997.

Presença, 1989.

The second I: Computers and the Human Spirit. Lisboa:Editorial WINNICOTT, Donald W. The environment and maturation processes: Emotional development theory studies. Porte Alegre. Artemed 1983 